\title{
Analisis Biaya Pemeliharaan Bangunan Gedung Dengan Konsep Green building Dan Bangunan Gedung Dengan Konsep Non Green building
}

\author{
Rika Apriani" ${ }^{* 1}$ Ida Ayu Ari Angreni \\ ${ }^{1}$ Mahasiswa, Program Magister, Jurusan Manajemen Rekayasa Infrastruktur, Fakultas Teknik Sipil \\ dan Perencanaan, Universitas Gunadarma \\ ${ }^{2}$ Dosen, Jurusan Manajemen Rekayasa Infrastruktur, Fakultas Teknik Sipil dan Perencanaan, \\ Universitas Gunadarma \\ E-mail: *1aprianirikaa@gmail.com
}

Received 16 August 2021; Reviewed 20 October 2021; Accepted 24 December 2021

Journal Homepage: http://jurnal.borneo.ac.id/index.php/borneoengineering

\begin{abstract}
The concept of green building must also consider the cost of building maintenance in the postconstruction stage so as not to reduce the large company costs each year. Green building is defined as a high-performance building that is made environmentally friendly, economically beneficial and healthy for life and workplace. This study intends to analyze the cost of building maintenance using the concept of green building non-green building. The data used in this study is the data on the maintenance costs of green buildings and non-green buildings. This data was taken by surveying the building management directly. Based on the analysis, the difference in the cost of maintaining green buildings and non-green buildings is Rp 10,283.22/m2/year. Based on the calculation, the maintenance costs of green building and non-green building still conform the standards of the Minister of Public Works Regulation and the standard of the Minister of Finance Regulation.
\end{abstract}

Keywords: Green building, Cost, Maintenance, Environment, Building management

\begin{abstract}
Abstrak
Pemeliharaan bangunan sudah menjadi persyaratan yang harus dipenuhi, utamanya bagi bangunan yang difungsikan untuk kepentingan umum. Tidak berbeda dengan bangunan konvesional, bangunan dengan konsep green building pun harus dipertimbangkan biaya pemeliharaan bangunan pada tahap pascakonstrusi agar tidak menekan biaya perusahaan yang besar tiap tahunnya. Green building didefinisikan sebagai gedung berkinerja tinggi yang dibuat berwawasan lingkungan, menguntungkan secara ekonomi dan sehat bagi kehidupan maupun tempat kerja. Penelitian ini bermaksud untuk menganalisis biaya pemeliharaan bangunan gedung menggunakan konsep green building dan konsep non green building.Metode yang digunakan pada penilitian ini adalah Uji Statistik Beda Dua Mean. Data yang dibutuhkan merupakan data biaya pemeliharaan yang diperoleh dari pengelola gedung. Berdasarkan analisis selisih biaya pemeliharaan green building dan non green building adalah sebesar Rp 10.283,22 permeter persegi pertahun. Berdasarkan hasil perhitungan diketahui bahwa biaya pemeliharaan yang terdapat pada bangunan dengan konsep green building dan non green building masih memenuhi standar Peraturan Menteri Pekerjaan Umun dan standar Peraturan Menteri Keuangan.
\end{abstract}

Kata kunci: Green building, Pemeliharaan, Biaya, Lingkungan, Pengelola gedung 


\section{Pendahuluan}

Salah satu penyebab pemanasan global yang terjadi saat ini adalah adanya bangunan-bangunan tinggi. Akibatnya, intensitas curah hujan yang sangat tinggi dan cuaca panas yang sangat panjang terasa pada saat ini. Tindakan yang dapat dilakukan dalam mengatasi hal tersebut adalah dengan penggunaan konsep "Green building" dalam pembangunan dan penggunaan gedung. Adapun faktor lainnya yaitu dari aspek biaya (coast) perawatan bangunan. Anggaran biaya untuk pemeliharan maupun perawatan bangunan dapat dikatakan cukup tinggi. Dalam sebuah artikel majalah konstruksi tahun1999 mengenai "Ilmu ekonomi Teknik bagi optimasi perawatan gedung", durasi pemeliharaan bangunan meliputi $80.1 \%$, pembuatan konsep $10 \%$, perencanaan $6.6 \%$ dan konstruksi $3.3 \%$ dari umur total bangunan. Dari sana dapat dilihat bahwa proses pemeliharaan bangunan mempunyai durasi waktu yang lama yaitu 80.1\% dari umur bangunan, (Yatna, 2011).

Menurut Intan,(2015) penerapan green building di Indonesia berjalan sangat lambat karena masih banyak anggapan akan pertimbangan modal awal yang besar. Pada penelitian serupa, hal menyebabkan besarnya modal awal Pembangunan Bangunan yang berstandar GBCI terdapat pada aspek konstruksi pada variabel aspek BEM diakibatkan oleh Proper Comissiong. Hal ini diakibatkan oleh proses yang dilakukan harus sesuai standar GBCI, yang jauh lebih rumit dan berbeda dari comissioning yang dilakukan pada gedung biasa. Pelaksanaan proper commissioning bisa memakan waktu satu minggu, tergantung berapa banyak item yang akan di comissioning dan pelaksanaannya harus didokumentasi dan diawasi dengan ketat, sehingga membuat variabel ini akan memakan biaya yang besar. Dan penilitian ini diperoleh pengaruh biaya akibat penerapan BEM sebesar 0,54\% (Florina, 2019).

Saat ini Indonesia telah membentuk emerging member dengan label Green building Council Indonesia (GBCI) untuk mensukseskan konsep green building di Indonesia. Saat ini baru terdapat 20 gedung yang bersertifikat green building yang terdapat di Indonesia. Salah satunya yaitu gedung Utama Kementerian PUPR (GBCI, 2018).

United States Green building Council (USGBC) memberikan definisi green building sebagai gedung berkinerja tinggi yang dibuat berwawasan lingkungan, menguntungkan secara ekonomi dan sehat bagi kehidupan maupun tempat kerja. Aspek lingkungan yang ditinjau di antaranya berkaitan dengan pengelolaan waste material (material sampah), air dan pilihan bahan konstruksi yang digunakan, harus sesedikit mungkin atau tidak menimbulkan dampak negatif pada lingkungan (Fery, 2015).

McLennan (2004) juga mendefinisikan green building sebagai suatu sistem struktur atau bangunan yang diakui secara hukum sebagai produk yang bisa didaur ulang atau minimum dampak negatifnya terhadap lingkungan. Sebagai standar dan parameter green building di Indonesia maka Green building Council Indonesia membuat ringkasan tolak ukur yang digunakan dalam mensertifikasi gedung yang telah menggunakan konsep green building di Indonesia. Aturan ini terdapat di Greenship Rating Tools untuk Gedung Terbangun Versi 1.0 tentang Ringkasan Tolak Ukur.

Pemeliharaan bangunan secara konsisten sudah menjadi persyaratan yang harus dipenuhi, utamanya bagi bangunan yang difungsikan untuk kepentingan umum. Secara rasional tingkat kemudahan pemeliharaan sebuah bangunan secara signifikan akan mempengaruhi besarnya biaya pemeliharaan setiap tahunnya. Pemeliharaan dan pengawasan secara kontinyu terhadap kondisi komponenkomponen bangunan gedung akan sangat membantu untuk menekan pembiayaan yang besar serta dapat mengurangi tingkat kerusakan yang parah. Tidak berbeda dengan bangunan konvesional bangunan dengan konsep green building pun harus dipertimbangkan biaya pemeliharaan dan perawatan bangunan pada tahap pascakonstrusi agar tidak menekan biaya perusahaan yang besar tiap tahunnya (Amal, 2015). 
Penelitian ini bermaksud untuk menganalisis biaya pemeliharaan dan perawatan bangunan gedung menggunakan konsep konvensional yang ditinjau melalui gedung Mahkamah Konstitusi RI dan gedung dengan konsep green building yang ditinjau melalui gedung gedung Utama Kementerian PUPR. Penelitian ini mengacu pada peraturan Menteri Pekerjaan Umum Nomor 24/PRT/M/2008 tentang Pedoman dan pemeliharaan Perawatan Bangunan Gedung dan peraturan Menteri Keuangan Republik Indonesia Nomor 37/PMK.02/2018 tentang Standar Biaya Masukan Tahun Anggaran 2018. Apabila ditemukan biaya pemeliharaan gedung yang melebihi standar satuan biaya pemeliharaan gedung yang ditetapkan dalam peraturan Menteri Keuangan Republik Indonesia Nomor 37/PMK.02/2018 tentang Standar Biaya Masukan Tahun Anggaran 2018 maka akan dianalisis faktor yang mempengaruhi besarnya biaya pemeliharaan pada gedung tersebut. Adapun pentingnya penelitian ini adalah membantu proses audit baik dari segi parameter fisik bangunan maupun dari segi biaya, sehingga dapat menjadi usulan baik berupa anggaran ataupun item yang menjadi fokus khususnya dalam perawatan dan pemeliharan bangunan di waktu mendatang. Penelitian terdahulu yang terkait dengan penelitian ini adalah "A Study to Compare the Cost of Operation and Maintenance in Green building Index (GBI) and Non-Green building Index (NonGBI) Rated Building in Malaysia”. Lee Zheng Ping dan Chu Hui Chen (2016) mengumpulkan dan menganalisis biaya operasional dan pemeliharaan gedung antara bangunan yang mendapat GBI dan bangunan-bangunan yang tidak mendapat GBI di Malaysia yang lebih dari 2 tahun beroperasi penuh. Penelitian ini mengadaptasi metode pengumpulan data kualitatif melalui kriteria sampling yang berarti sampel yang dipilih untuk memenuhi beberapa kriteria seperti untuk studi kasus ini yaitu: tinggi bangunan/tingkat bangunan, tingkat hunian, total unit, luas lahan, mode bangunan, tahun operasi dan jenis bangunan. Hasil studi menyimpulkan $78,9 \%$ biaya penghematan terdapat pada gedung dengan konsep green building.

Di lain hal fungsi dari analisis biaya tersebut adalah sebagai bahan perhitungan yang dilakukan dengan mempertimbangkan pilihan yang diambil setelah masa layan bangunan habis. Masa layan bangunan diasumsikan hingga 30 tahun. Pilihan pertama adalah bangunan dihancurkan setelah melewati masa layannya, maka dari itu biaya demolisi diperhitungkan dalam perhitungan life-cycle cost. Pilihan kedua adalah bangunan dijual setelah melewati masa layannya, sehingga perhitungan life-cycle cost memperhitungkan nilai jual kembali Gedung Campus Center ITB. (Putro, 2019)

Adapun penelitian terdahulu lainnya yang terkait adalah "Analisa Pengaruh Penerapan Konsep Green building Terhadap Keputusan Investasi Pada National Hospital Surabaya". Tujuan penelitian tersebut yaitu analisa terhadap faktor-faktor apa saja yang mempengaruhi keputusan biaya investasi dan oprasional. Hasil dari penelitian ini diketahui penerapan green building pada National Hospital Surabaya diaplikasikan pada 3 Konsep Green yaitu Green Design, Green Material, dan Green Technology. Analisa dilakukan pada 3 fitur green building yaitu Kaca Sunergy, AC VRV III, dan Lampu LED. (Rizki dkk, 2014).

Trixy Firsani dan Christiono Utomo (2012) menganalisis seberapa besar biaya yang dikeluarkan oleh suatu bangunan berkonsep green building selama 10 tahun. Berdasarkan hasil analisa Life Cycle Cost dengan kategori biaya yang terdiri dari Biaya Awal, Biaya Energi, Biaya Operasional dan Pemeliharaan, serta Biaya Penggantian, diperoleh total biaya siklus Diamond Building Malaysia adalah sebesar RM 235.096.883atau sebesar Rp 759.290.649.000. Jika memasukkan Nilai Sisa dalam kategori biaya Life Cycle Cost tersebut, total biaya hidup Diamond Building menjadi RM 186.646.883 atau sebesar Rp 559.940.649.000.

Min Lin, Afshin Afshari, Elie Azar (2018) menyajikan analisis empiris mengenai konsumsi energy di sektor bangunan UEA dengan fokus khusus memakai parameter yang terkait dengan operasi dan pemeliharaan sistem bangunan. Berdasarkan penelitian ini diketahui parameter-parameter bangunan yang berdampak signifikan terhadap tingkat konsumsi energi, salah satunya adalah penggunaan AC, penggunaan jendela, dll. 


\section{Metode Penelitian}

Penelitian ini dibagi menjadi menjadi tiga tahap. Tahap pertama adalah pengumpulan data. Tahap kedua adalah analisis data, dan tahap ketiga adalah penarikan kesimpulan. Data yang dibutuhkan pada penelitian ini berupa data sekunder. Data sekunder yang dibutuhkan merupakan data biaya pemeliharaan yang diperoleh dari pengelola gedung. Lokasi penelitian atau bangunan gedung yang diangkat sebagai studi kasus dalam penelitian ini adalah 2 (dua) bangunan gedung yaitu: Gedung Utama Kementerian PUPR mewakili gedung dengan konsep green building dan Gedung Mahkamah Konstitusi Republik Indonesia mewakili gedung dengan konsep non green building.

Bagan alur penelitian ini adalah sebagai berikut:

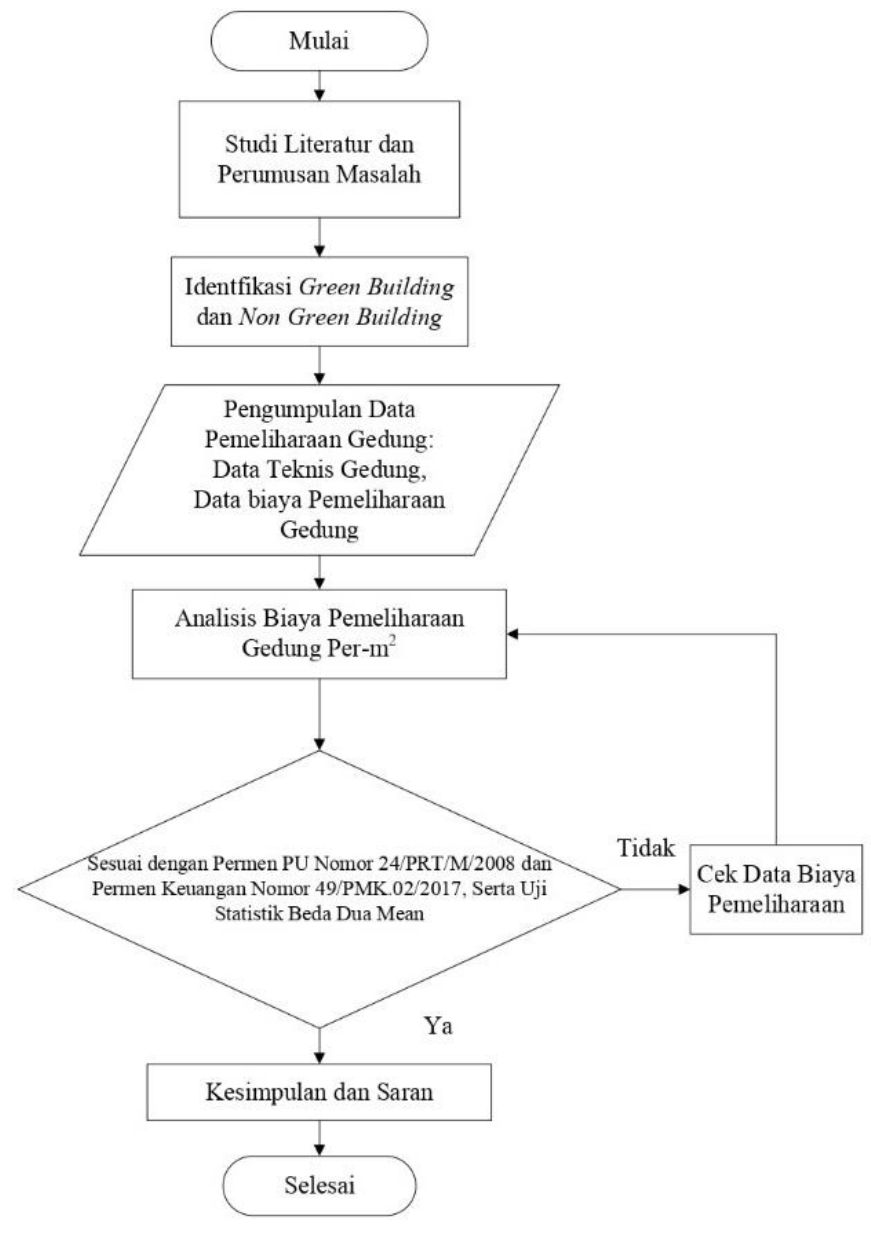

Gambar 1 Bagan Alur Penelitian

\subsection{Biaya Pemeliharaan}

Perhitungan biaya pemeliharaan gedung mengacu pada peraturan Menteri Pekerjaan Umum Nomor 24/PRT/M/2008 tentang Pedoman Pemeliharaan dan Perawatan Bangunan Gedung, serta peraturan Menteri Keuangan Republik Indonesia Nomor 49/PMK.02/2018 tentang Standar Biaya Masukan Tahun Anggaran 2018.

Menurut Peraturan Menteri Pekerjaan Umum Nomor 45/PRT/M/2007 tentang Pedoman Teknis Pembangunan Gedung Negara, harga satuan tertinggi rata-rata per- $\mathrm{m}^{2}$ bangunan gedung bertingkat 
adalah didasarkan pada harga satuan lantai dasar tertinggi per- $\mathrm{m}^{2}$ untuk bangunan gedung bertingkat, kemudian dikalikan dengan koefisien atau faktor pengali untuk jumlah lantai yang bersangkutan. Adapun nilai koefisien pengali tersebut adalah seperti pada Tabel 1.

\begin{tabular}{cc} 
Tabel 1 Klasifikasi Faktor Pengali & \\
\hline Jumlah Lantai Bangunan & Harga Satuan per-m² Tertinggi \\
\hline Bangunan 2 lantai & 1,090 Standar harga gedung bertingkat \\
Bangunan 3 lantai & 1,120 Standar harga gedung bertingkat \\
Bangunan 4 lantai & 1,135 Standar harga gedung bertingkat \\
Bangunan 5 lantai & 1,162 Standar harga gedung bertingkat \\
Bangunan 6 lantai & 1,197 Standar harga gedung bertingkat \\
Bangunan 7 lantai & 1,236 Standar harga gedung bertingkat \\
Bangunan 8 lantai & 1,265 Standar harga gedung bertingkat \\
\hline
\end{tabular}

Sumber: Dinas Pekerjaan Umum Cipta Karya, 2008

\begin{tabular}{cccc}
\multicolumn{2}{c}{ Tabel 2} & Standar Harga per-m & Tertinggi Prov. DKI Jakarta bangunan gedung \\
\hline \multirow{2}{*}{ No } & Jenis Bangunan & \multicolumn{2}{c}{ Standar Harga Bangunan Per $\mathbf{~ m}^{\mathbf{2}}\left(\mathbf{R p} / \mathbf{m}^{\mathbf{2}}\right)$} \\
\cline { 3 - 4 } & & Bertingkat & Tidak Bertingkat \\
\hline 1 & Bangunan Sederhana & 4.100 .000 & 3.650 .000 \\
2 & Bangunan Tidak Sederhana & 5.768 .000 & 4.300 .000 \\
\hline
\end{tabular}

Sumber: Dinas Pekerjaan Umum Cipta Karya, 2017

Menurut Peraturan Menteri Keuangan Republik Indonesia Nomor 49/PMK.02/2017 Tentang Standar Biaya Tahun Anggaran 2018 mengenai Satuan Biaya Pemeliharaan Gedung/Bangunan Dalam Negeri, satuan biaya pemeliharaan gedung/bangunan dalam negeri merupakan satuan biaya yang digunakan untuk perencanaan kebutuhan biaya pemeliharaan rutin gedung/ bangunan di dalam negeri dengan maksud menjaga/ mempertahankan gedung dan bangunan kantor di dalam negeri agar tetap dalam kondisi semula atau perbaikan dengan tingkat kerusakan kurang dari atau sama dengan $2 \%$ (dua persen).

\subsection{Uji Statistik Beda Dua Mean}

Uji statistik yang digunakan pada penelitian ini adalah Uji Beda Dua Mean. Uji beda dua mean dibagi dalam dua kelompok, Independen dan dependen. Independen, bila data kelompok yang satu tidak tergantung daridata kelompok kedua. Sedangkan, dependen, bila kelompok data yang dibandingkan datanya saling mempunyai ketergantungan (data sesudah dependen/tergantung dengan data sebelum) (Sabri, dkk, 2014).

1. Uji beda mean independen

Tujuan pengujian ini adalah untuk mengetahui perbedaan mean duakelompok data independen. Syarat atau asumsi yang harus dipenuhi adalahsebagai berikut:

a. Data berdistribusi normal atau simetris.

b. Kedua kelompok data independen.

c. Variabel yang dihubungkan berbentuk numerik dan kategori(dengan hanya dua kelompok).

Prinsip pengujian dua mean adalah melihat perbedaan variasi kedua kelompok data. Bentuk varian kedua kelompok data akan berpengaruh pada nilai standard error yang akhirnya akan membedakan rumus pengujiannya. Tujuan dari uji ini untuk mengetahui varian antara kelompok data satu apakah sama dengan kelompok data yang kedua. 
2. Uji beda mean dependen

Tujuan untuk menguji perbedaan antara dua kelompok data yang dependen. Syarat uji beda mean dependen adalah sebagai berikut:

a. Distribusi data normal

b. Kedua kelompok data dependen/ pair

c. Jenis variabel: numerik dan kategori (dua kelompok)

\section{Hasil dan Pembahasan}

\subsection{Gedung Utama Kementerian PUPR}

Gedung utama kementerian PUPR mulai beroperasi sejak diresmikan penggunaannya pada Januari 2012. Pembangunan Gedung Utama Kementerian Pekerjaan Umum dimulai pada tanggal 08 Desember 2010 dan selesai pada tanggal 12 Desember 2011. Proses pelaksanaan konstruksi terhitung 371 hari kerja, dengan masa pemeliharaan selama 180 hari. Gedung ini memiliki luasan bangunan sebesar $28.610 \mathrm{~m}^{2}$, dan tinggi 74,5 $\mathrm{m}$.

Gedung ini dinobatkan sebagai pioneer (pilot project) green building di Indonesia. Setelah dilakukan audit oleh GBCI pada tahun 2011, berdasarkan kriteria yang telah ditetapkan, gedung ini mendapat predikat 'platinum' dengan skor 74 (tujuh puluh empat). Poin selengkapnya ditunjukkan pada Tabel 3.

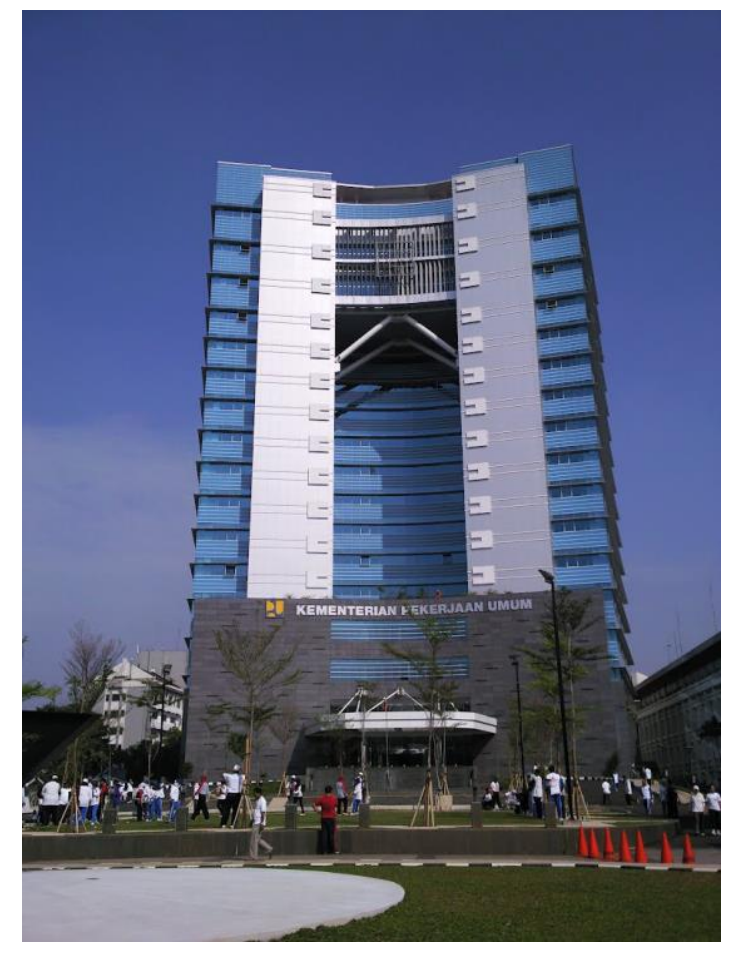

\section{Gambar 2 Gedung Utama Kementerian PUPR}

Pada Gedung Utama Kementerian PU ini terdapat beberapa variabel yang meliputi; biaya kebersihan, biaya operasional peralatan, biaya perawatan consumable dan non consumable material, biaya periodic comissioning, biaya keamanan, biaya pemeliharaan feature green building, biaya pemeliharaan green area, dan biaya penggantian komponen MEP. Rangkuman biaya pemeliharan gedung utama kementerian PUPR pada tahun 2013 dapat dilihat pada Tabel 4. 
Tabel 3 Rating Gedung Utama Kementerian PUPR

\begin{tabular}{lc}
\multicolumn{1}{c}{ Kategori } & Poin Gedung Kementerian PU \\
\hline Appropriate Site Development - ASD & 13 \\
Energy Efficiency and Conservation - EEC & 15 \\
Water Conservation - WAC & 18 \\
Material Resource and Recycle - MRC & 9 \\
Indoor Air Health and Comfort - IHC & 8 \\
Building Environment Management - BEM & 11 \\
\hline Total & 74
\end{tabular}

Sumber: GBCI, 2018

Tabel 4 Biaya pemeliharaan Gedung PUPR tahun 2013

\begin{tabular}{lc}
\hline \multicolumn{1}{c}{ Uraian } & Total Biaya (Rp) \\
\hline Biaya Kebersihan & 993.938 .400 \\
Biaya Operasional Peralatan MEP & 626.934 .000 \\
Perawatan Consumable Material & 138.000 .000 \\
Perawatan non-Consumable Material & 150.000 .000 \\
Biaya Periodic Comissioning & 300.000 .000 \\
Biaya Keamanan & 42.597 .360 \\
Biaya Pemeliharaan Feature Green building & 165.000 .000 \\
Biaya Pemeliharaan Green Area & 56.796 .480 \\
Biaya Penggantian Komponen MEP & 11.579 .760 \\
\hline Total Biaya & 2.286 .058 .320 \\
\hline
\end{tabular}

\subsection{Gedung Mahkamah Konstitusi RI}

Gedung Mahkamah Konstitusi RI adalah salah satu gedung perkantoran negara yang terletak di daerah Jakarta Pusat. Gedung ini memiliki desain gedung gaya neo klasik ala Yunani atau Romawi kuno. Pembangunan gedung Mahkamah Konstitusi ini dimulai pada tanggal 17 Juni 2005 dan selesai pada tanggal 13 Agustus 2007. Gedung ini memiliki luasan bangunan sebesar $24.000 \mathrm{~m}^{2}$ yang terdiri atas 16 lantai utama dan dua basement. Biaya pemeliharaan pada Gedung Mahkamah Konstitusi RI dapat dilihat pada Tabel 5 .

Tabel 5 Biaya pemeliharaan Gedung Mahkamah Konstitusi RI tahun 2013

\begin{tabular}{lc}
\hline \multicolumn{1}{c}{ Uraian } & Total Biaya (Rp) \\
\hline Peralatan Housekeeping Gedung MK & 738.000 .000 \\
Peralatan dan bahan habis pakai Houskeeping dan security & 149.502 .800 \\
Suku cadang pekerjaan ME & 535.000 .000 \\
Pengadaan Material ME Rutin & 168.000 .000 \\
Pemeliharaan Peralatan ME Khusus & 323.400 .000 \\
\hline \multicolumn{1}{c}{ Total Biaya } & $\mathbf{1 . 6 7 0 . 9 0 2 . 8 0 0}$ \\
\hline
\end{tabular}

\subsection{Analisis Biaya Pemeliharaan Green building dan Non Green building}

Besarnya biaya pemeliharaan suatu gedung berbeda-beda tergantung pada fungsi gedung, dan fiturfitur yang digunakan pada gedung tersebut. Begitu pula pada gedung green building dan non green building, perbedaan biaya pada kedua gedung tersebut dapat dilihat pada Gambar 4. 


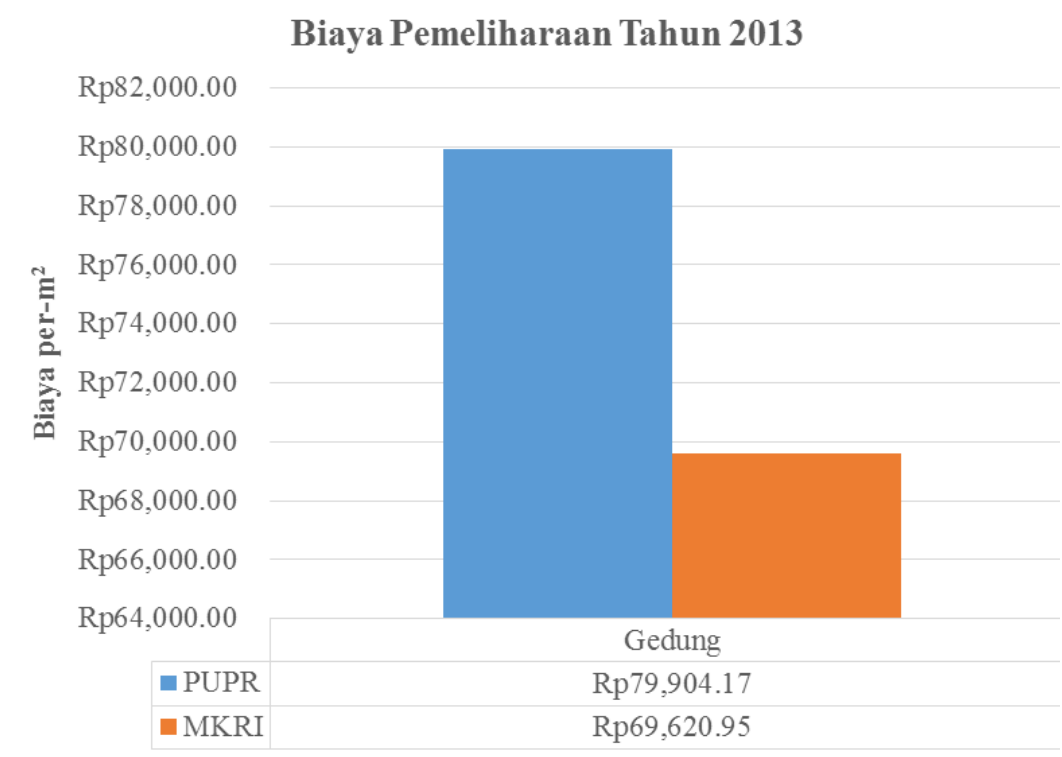

Gambar 4 Grafik Biaya Pemeliharaan Gedung MKRI dan PUPR Tahun 2013

Berdasarkan Gambar 4 diketahui terjadi perbedaaan biaya pemeliharaan permeter persegi pada green building yang diwakili oleh Gedung Utama Kementerian PUPR dan non green building yang diwakili oleh Gedung Mahkamah Konstitusi. Berdasarkan Gambar 4 diketahui biaya pemeliharaan Gedung Utama Kementerian PUPR sebesar Rp 79.904,17 (tujuh puluh sembilan ribu sembilan ratus empat koma tujuh belas rupiah) permeter persegi, sedangkan biaya pemeliharaan Gedung Mahamah Konstitusi sebesar Rp 69.620,95 (enam puluh sembilan ribu enam ratus dua puluh koma sembilan puluh lima rupiah) permeter persegi. Harga biaya pemeliharaan tersebut berasal dari pembagian biaya pemeliharaan kedua gedung dibagi masing-masing luasan gedung yaitu $28.610 \mathrm{~m}^{2}$ untuk Gedung Utama Kementerian PUPR dan $24.000 \mathrm{~m}^{2}$ Untuk Gedung Mahkamah Konstitusi. Faktor yang menyebabkan perbedaan pada biaya pemeliharaan Gedung Utama Kementerian PUPR dan Gedung Mahkamah Konstitusi yaitu terdapat pada fitur-fitur yang digunakan pada gedung tersebut. Seperti adanya biaya tambahan dalam perawatan fitur-fitur green building seperti sensor-sensor pengatur cahaya dan suhu yang terdapat pada Gedung Kementerian PUPR, sehingga hal ini memperbesar biaya pemeliharaan pada gedung dengan konsep green building. Penambahan biaya pemeliharaan green area juga menjadi salah satu faktor penyebab perbedaan biaya pemeliharaan pada kedua gedung tersebut.

\subsection{Analisis Biaya Pemeliharaan Green building dan Non Green building Berdasarkan Standar Harga yang Berlaku}

Tabel 6 adalah data biaya pemeliharaan dan perawatan kedua gedung pada tahun anggaran 2013 jika dibandingkan dengan Peraturan Menteri Pekerjaan Umum Nomor 45/PRT/M/2007 tentang Pedoman Teknis Pembangunan Gedung Negara.

Tabel 6 Data Biaya Pemeliharaan dan Perawatan Kedua Gedung Standar Permen PU

\begin{tabular}{cccc}
\hline No & Jenis Gedung & $\begin{array}{c}\text { Biaya 2013 } \\
(\mathbf{R p})\end{array}$ & $\begin{array}{c}\text { Biaya Permen PU } \\
(\mathbf{R p})\end{array}$ \\
\hline 1 & Gedung PUPR & 2.286 .058 .320 & 4.175 .068 .744 \\
2 & Gedung MK & 1.670 .902 .800 & 3.502 .329 .600 \\
\hline
\end{tabular}


Perhitungan biaya pemeliharaan gedung sesuai dengan standar Permen PU diperoleh dari $2 \%$ biaya pembangunan gedung. Dimana biaya pembangunan gedung merupakan hasil pengalian standar harga, faktor pengali, dan luasan gedung.

Besarnya biaya pemeliharaan gedung juga diatur oleh Peraturan Menteri Keuangan Republik Indonesia Nomor 37/PMK.02/2012 Tentang Standar Biaya Tahun Anggaran 2013 mengenai Satuan Biaya Pemeliharaan Gedung/Bangunan Dalam Negeri. Sesuai dengan peraturan tersebut dapat diketahui untuk Prov. DKI Jakarta Biaya Pemeliharaan sebesar Rp $153.000 \mathrm{~m}^{2} /$ tahun. Perbandingan biaya pemeliharaan gedung PUPR dan gedung Mahkamah Konstitusi dengan peraturan Menteri Keuangan dapat dilihat pada Tabel 7.

Tabel 7. Data Biaya Pemeliharaan dan Perawatan Kedua Gedung Standar Menteri Keuangan

\begin{tabular}{llcc}
\hline No & \multicolumn{1}{c}{ Jenis Gedung } & $\begin{array}{c}\text { Biaya 2013 } \\
(\mathrm{Rp})\end{array}$ & $\begin{array}{c}\text { Biaya Menteri Keuangan } \\
(\mathrm{Rp})\end{array}$ \\
\hline 1 & Gedung PUPR & 2.286 .058 .320 & 4.377 .330 .000 \\
2 & Gedung MK & 1.670 .902 .800 & 3.672 .000 .000 \\
\hline
\end{tabular}

Berdasarkan hasil perhitungan tersebut diketahui bahwa biaya pemeliharaan yang terdapat pada kedua gedung tersebut masih memenuhi standar Peraturan Menteri Pekerjaan Umun dan standar Peraturan Menteri Keuangan.

\subsection{Analisis Biaya Pemeliharaan Green building dan Non Green building Berdasarkan Standar Harga yang Berlaku}

Pengujian statistik beda dua mean yang dilakukan pada analisis data pemeliharaan gedung green building dan gedung non green building menggunakan pengujian dengan uji untuk varian berbeda dengan rumusan sebagai berikut:

$$
\begin{aligned}
& \mathrm{T}_{\text {hitung }}=\frac{\left(\mathrm{X}_{1}-\mathrm{X}_{2}\right)}{\sqrt{\left(\mathrm{S}_{1}^{2} / \mathrm{n}_{1}\right)+\left(\mathrm{S}_{2}^{2} / \mathrm{n}_{2}\right)}} \\
& \mathrm{df}=\frac{\left[\left(\mathrm{S}_{1}^{2} / \mathrm{n}_{1}\right)+\left(\mathrm{S}_{2}^{2} / \mathrm{n}_{2}\right)\right]^{2}}{\left[\left(\mathrm{~S}_{1}^{2} / \mathrm{n}_{1}\right)^{2} /\left(\mathrm{n}_{1}-1\right)\right]+\left[\left(\mathrm{S}_{2}^{2} / \mathrm{n}_{2}\right)^{2} /\left(\mathrm{n}_{2}-1\right)\right]}
\end{aligned}
$$

Keterangan:

$\mathrm{n}_{1}$ atau $\mathrm{n}_{2} \quad$ : Jumlah sampel kelompok 1 atau 2

$\mathrm{S}_{1}$ atau $\mathrm{S}_{2} \quad$ : Standar deviasi sampel kelompok 1 atau 2

$\mathrm{X}_{1}$ atau $\mathrm{X}_{2} \quad$ : Rata-rata sampel kelompok 1 atau 2

df $\quad$ : Derajat bebas

Hipotesa yang digunakan pada pengujian ini adalah sebagai berikut:

$\mathrm{H}_{0}$ : Pemeliharaan green building memerlukan biaya lebih besar dari non green building

$\mathrm{H}_{\mathrm{a}}$ : Pemeliharaan green building tidak memerlukan biaya lebih besar dari non green building 
Data yang digunakan dalam pengujian beda dua mean adalah data biaya pemeliharaan aktual, dan data biaya pemeliharaan yang diperhitungkan menggunakan rumusan peraturan menteri PUPR dan kementerian keuangan. Berikut data serta hasil perhitungan biaya pemeliharaan gedung dengan konsep green building dan gedung dengan konsep non green building.

Tabel 8. Uji Statistik Biaya Pemeliharaan Gedung PUPR dan MKRI

\begin{tabular}{lcc}
\hline \multicolumn{1}{c}{ Deskripsi } & Gedung PUPR & Gedung MKRI \\
\hline Biaya perhitungan Permen PU & $4.175 .068 .744,00$ & $3.502 .329 .600,00$ \\
Biaya perhitungan Menteri Keuangan & $4.377 .330 .000,00$ & $3.672 .000 .000,00$ \\
Biaya aktual 2013 & $2.286 .058 .320,00$ & $1.670 .902 .800,00$ \\
Biaya aktual 2012 & $2.144 .669 .864,00$ & - \\
Rata-rata (X) & $3.245 .781 .732,00$ & $2.948 .410 .800,00$ \\
Jumlah data (n) & 4 & 3 \\
Standar devsiasi (S) & $1.194 .081 .544,80$ & $1.109 .602 .193,90$ \\
\hline
\end{tabular}

Maka,

$$
\begin{aligned}
\mathrm{T}_{\text {hitung }} & =\frac{(3 \cdot 245 \cdot 781 \cdot 732,00-2 \cdot 948 \cdot 410 \cdot 800,00)}{\sqrt{\left(1 \cdot 194 \cdot 081 \cdot 544,80^{2} / 4\right)+\left(1 \cdot 109.602 .193,90^{2} / 3\right)}} \\
\mathrm{T}_{\text {hitung }} & =0,34
\end{aligned}
$$

Berdasarkan perhitungan $T$ dapat diketahui bahwa $T_{\text {hitung }}$ diperoleh sebesar 0,34, sedangkan $T_{\text {tabel }}$ dengan taraf nyata 5\% $(=0,05)$ dan derajat kebebasan 5 diperoleh sebesar 2,571. Derajat kebebasan diperoleh berdasarkan perhitungan sebagai berikut:

$$
\begin{aligned}
\text { df } & \left.=\frac{\left[\left(1.194 .081 .544,80^{2} / 4\right)+\left(1.109 .602 .193,90^{2} / 3\right)\right]^{2}}{\left[\left(1.194 .081 .544,80^{2} / 4\right)^{2} /(4-1)\right]+\left[\left(1.109 .602 .193,90^{2} / 3\right)^{2}\right.} /(3-1)\right] \\
\text { df } & =5
\end{aligned}
$$

Maka dapat disimpulkan $\mathrm{T}_{\text {hitung }}<\mathrm{T}_{\text {tabel }}$, hal ini menunjukan bahwa $\mathrm{H}_{0}$ dapat diterima atau pemeliharaan green building memerlukan biaya lebih besar dari non green building.

\section{Kesimpulan}

Selisih biaya pemeliharaan green building dan non green building adalah sebesar $\mathrm{Rp} 10.283,22$ permeter persegi pertahun. Berdasarkan data diketahui biaya pemeliharaan green building lebih besar dari non green building, faktor penyebab perbedaan biaya pemeliharaan ini terdapat pada tambahan biaya pemeliharaan untuk fitur-fitur yang digunakan dalam green building dan pemeliharaan green area. Berdasarkan hasil perhitungan diketahui bahwa biaya pemeliharaan yang terdapat pada kedua gedung masih memenuhi standar Peraturan Menteri Pekerjaan Umun dan standar Peraturan Menteri Keuangan.

\section{Daftar Pustaka}

Amal, Bahar. 2015. Analisis Biaya Pemeliharaan dan Perawatan Bangunan Gedung Pada Kantor Pemerintah Dan Kantor Swasta. Universitas Gadjah Mada. Yogyakarta. 
Firsani, Trixy dan Utomo, Christiono. 2012. Analisa Life Cycle Cost pada Green building Diamond Building Malaysia. Jurnal Teknik ITS 1(1). ISSN: 2301-9271. Surabaya

Green building Council Indonesia. 2018. Online. Diakses melalui: http://www.gbcindonesia.org/greenship.

Lin, Min dkk. (2018). A data-driven analysis of building energy use with emphasis on operation and maintenance: A case study from the UAE. Journal of Cleaner Production 192: 169-178. Abu Dhabi.

McLennan, J.R., 2004. The Philosophy of Sustainable Design. Ecotone Publishing Company LLC, Kansas City, Missouri.

Peraturan Menteri Pekerjaan Umum tentang Pedoman Teknis Pemeliharaan dan Perawatan Bangunan Gedung Nomor 24/ PRT/M/2008. (2008). Indonesia.

Peraturan Menteri Keuangan tentang Standar Biaya Masukkan Tahun Anggaran 2013 Nomor 37/ PMK.02/2012. (2012). Indonesia.

Ping, Lee Zheng dan Chen, Chu Hui. 2016. A Study to Compare the Cost of Operation and Maintenance in Green building Index (GBI) and Non-Green building Index (NonGBI) Rated Building in Malaysia. Matec Web of Conference 66(00028). Malaysia.

Sabri, Luknis, Hastono, Sutanto Priyo. 2014. Statistik Kesehatan. Jakarta.

Supriyatna, Y., 2011. Estimasi Biaya Pemeliharaan Bangunan Gedung. Majalah Ilmiah UNIKOM.

Yuliatna, Fery. 2015. Analisis Perbandingan Konsumsi Energi Pada Kegiatan Operasional dan Pemeliharaan Bangunan Gedung dengan Konsep Green building dan Bangunan Gedung Konvensional. Tesis. Universitas Gajah Mada. Yogyakarta.

Andini, R. and Utomo, C., 2014. Analisa Pengaruh Penerapan Konsep Green building Terhadap Keputusan Investasi pada National Hospital Surabaya. Jurnal Teknik ITS, 3(2), pp.C53-C56.

Mayasari, I. and Utomo, C., 2015. Konsep Analisa Pengaruh Kriteria Green building Terhadap Keputusan Investasi Pada Pengembang Properti di Surabaya. In Prosiding Seminar Nasional Manajemen Teknologi XXII., Program Studi MMT-ITS, Surabaya (Vol. 24).

Putri, F.H.U., 2019. Pengaruh Aspek Building Environmental Management terhadap Biaya Konstruksl Green building.

Putro, R.W.S., 2019. Analisis life cycle cost pada green building dengan peringkat platinum di Indonesia (studi kasus: Alamanda Tower). SKRIPSI-2019. 